\title{
The Role of Strategic Brightness and Entrepreneurship in Achieving High Performance Gains
}

\author{
Hani Fadhil Jumaah Al-Shawi
}

Work place: Teaching in the Department of Business Administration, Shatt Al-Arab University College, Basra, Iraq. E-mail: dr.hanishawi@gmail.com

Received: November 24, 2021

Accepted: December 15, 2021

Online Published: December 21, 2021

doi:10.11114/bms.v7i4.5427

URL: https://doi.org/10.11114/bms.v7i4.5427

\begin{abstract}
The current research deals with everything related to activating the contemporary leadership style for business organizations according to their modern models (developmental, results, integrative, personal), as the style is chosen according to the leader's strategic repertoire and his inspirational powers in a specific position.

As a result of the rapid developments and rapid changes in recent years and the intensification of competition in the markets as a whole, which made most organizations guarantee for themselves survival and sustainability in the markets and the results of their work achieved by the management approach to controlling their work and this is done according to the perspective of ingenuity or organizational creativity with the support of their thinkers.

From here, the researcher identified the problem of the research with the question that confirms the extent to which it is possible to benefit from the level of creativity in the minds of the leaders of our local institutions, and what is their role in getting rid of routine obstacles that increase organizational deterioration to reach the pioneering performance in all their businesses. The aim of the current research is to analyze and explore the degree of strategic brightness in the commercial sector in Basra, to diagnose the relative importance of the components of strategic leadership in the environment of commercial activity and to try to analyze the level of awareness of the issue of creativity as an initiative. The business of modern Basra, namely (Al-Madda and Al-Taif companies), amounting to (25) individuals out of a total of (35) individuals, at a rate of (71\%). Descriptive and inferential tests will be conducted, the aim of which is to test the correlation and influence relationships between the variables of strategic brightness and investment leadership to gain the benefits of high performance and competitive advantage based on creativity and leadership, starting from leading and extending towards the endless competition in the market.
\end{abstract}

Keywords: creativity, organizational logic, deconstructive creativity, ingenuity, sustainability, survival, investment leadership

\section{Introduction}

The current research aims to identify initiatives that are commensurate with ambiguous situations to develop appropriate solutions by employing types of strategies that are compatible with the multiple fluctuations in potential environments, through the investment of the creative strategic resource. Exploiting investment opportunities compared to its competitors according to the principle of watch and gamble

The research structure included Five sections. The first was devoted to the presentation and discussion of the scientific methodology, and the second dealt with a discussion of the intellectual foundations and premises of competitive theories and some success models and their relevant conceptual foundations. The relationship with the investment of strategic ammunition, and the presentation and discussion of theoretical frameworks related to the manifestations of creativity, while the third topic focused on the problem of strategic management, and the fourth topic was the share of analyzing and discussing the results of the model test and research hypotheses, and finally a study of conclusions and recommendations.

\section{The First topic: Methodology of Research}

\subsection{The Problem of Research}

The research sub-questions were: 
What is the size of the repertoire of strategic leadership and creativity in the minds of the leaders of local commercial activity represented by some Basra companies?

What is its role in eliminating obstacles to high performance to reach superior or hoped-for performance?

\subsection{The Importance of Research}

The importance of the research as it deals with a contemporary strategic topic that has attracted the attention of many researchers in the era of competition and the high intensity of competition between business organizations, especially in the era of modern technology, which required these organizations to immediately initiate pro-active strategies in light of the complexity of environmental conditions to create opportunities and intelligently confront external challenges.

\subsection{Research Objectives}

This modest scientific contribution comes in harmony with the concerns shown by the literature in the impact of the super strategic initiatives in achieving entrepreneurship, and they have these interests:

1- Analysing the strategic leadership opportunities in the commercial activity in Basra.

2- Diagnosing the relative importance of the components of strategic leadership and estimating the technical level of the possibility of improving the business environment.

3- Analysing the level of awareness of the meanings and concepts of leadership and strategic leadership in managing local commercial activity companies.

4- Providing recommendations that contribute to activating the organizations' ownership of the strategic initiative .

\subsection{The Hypothesis Research Model and the Research Hypotheses}

\subsubsection{Hypothesis Research Model}

The hypothesis of the current research was developed to reflect the dimensions and variables of the researched phenomenon represented by the research questions and their basic premises, which provided for the analysis and diagnosis of the role of strategic business leadership in achieving superior competitive performance? . As shown in Figure (1), the hypothetical scheme consists of three components, the first component (independent) represented by the requirements of strategic leadership in terms of its dimensions and its seven sub-variables, namely (trust, commitment, control, commitment and synergy, experience, learning, stability) The second component of the study model is the high performance gains, which is the (dependent) component represented by its sub-dimensions ) competitive advantage in product leadership, customer interaction, operational superiority, long-term stakeholder value.

The third component (the mediator) represented by creativity, which was measured in terms of indicators (breaking down obstacles and removing barriers between departments, facing challenges by ditching and penetrating the ranks of competitors, optimal exploitation of opportunities, searching for new opportunities, flexibility of the organizational structure). The researcher tried to embody the reality of the basic role of the strategic initiative and its essential implications.

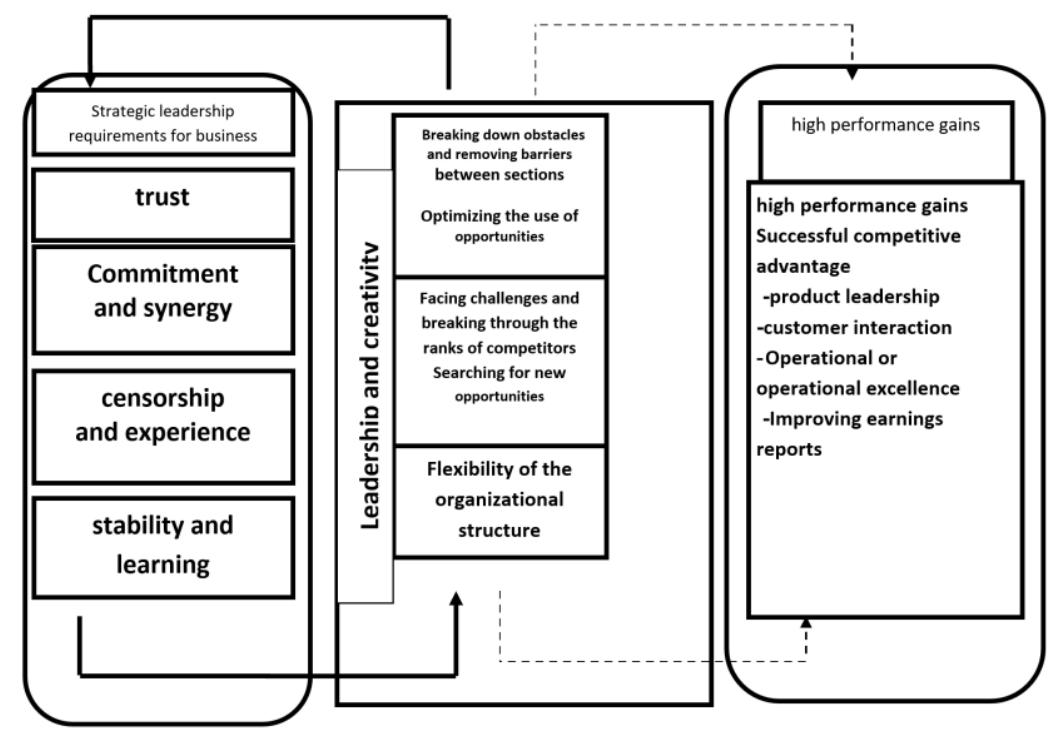

Figure 1. Hypothesis Research Model 


\subsubsection{Research Hypotheses:}

Two main hypotheses emerged from the current research model, as follows:-

1- There is a statistically significant correlation between the strategic initiative and high performance gains that contribute to achieving success in the commercial activity of the business companies surveyed.

2- There is a significant statistically significant impact relationship between strategic leadership and creativity that contributes to achieving high performance in the business companies surveyed.

\subsection{Research Sample}

A number of leaders in the commercial sector in Basra were elected from among the employees in leading administrative positions in the ( Al-Madda and Al-Taif Companies), and their number reached (25) individuals.

\subsection{Data Collection and Analysis Methods}

The researcher used several methods to collect data, including:

(1) Review of books, scientific journals and all local publications related to the concept of strategic leadership and organizational creativity.

(2) Review of what was published on the Internet in the field of initiative opportunities towards strategic leadership for companies looking to achieve high performance gains and competitive advantage.

(3) The questionnaire.

\subsection{Methods of Data Analysis}

(1)Descriptive statistical methods in terms of indicators of descriptive statistical analysis.

(2)T-test in the statistical program (Spss ) .

(3)Correlation, arithmetic means, standard deviations, and interpretation coefficient.

\section{The Second Topic: A review of theories related to competition for strategic leadership.}

The emergence of the concepts of competitive advantages was not a substitute for the concepts of comparative advantages except after several experiments in which Adam Smith, author of the book The Wealth of Nations in (1787), the British scientist David Ricardo (1835) and Michael Porter (1985) went through every hundred years. Approximately a year, which is the time difference between the economic conditions, theories of their era, and the thinking pattern of their generation, and we will try to list them as follows:-

\subsection{The Old Theories}

\subsubsection{Absolute Advantage Theory}

The first was developed by the British Adam Smith in (1787) (the father of modern economics in his book The Wealth of Nations), this theory calls on countries to specialize in production on the basis of criteria including (labor is the basis of value, the stability of unit cost regardless of the size of their production, the impossibility of transferring the elements of production technology between Countries (outside the country), ease of movement of production elements in the country, lack of transportation, transportation and extraction expenses, complete competition between industries in the country, full employment in the country, bartering goods for goods instead of money.

This theory is an economic thought that takes into account the privacy of countries, and specialization against international competition. The criticism directed at this thought (its inability to justify in the case of an absolute advantage in more than one commodity).

\subsubsection{Comparative Advantage Theory}

British scientist David Ricardo in (1835) (at the regional level). This theory is based on the principle of (work on the basis of value), that is, the price of a commodity is determined by the amount of work expended to produce it, and it is also called (the theory of relative cost).

\subsubsection{Theory of Relativistic Factors}

This theory is attributed to both Scottish scholars ( Hecksher and Olin). They canceled the previous two theories for their inability to keep pace with reality, and they were based on the basis of trade in cash and not on commodity barter.

Their theory is based on two assumptions:

The first: the principle of relative abundance of materials (each country produces goods that depend on the element that is abundant in it), for example, Canada produces timber due to the abundance of forests and the abundance of land, and China produces clothes due to the large number of workers and the abundance and cheapness of the cotton crop. 
The second :The principle of international exchange (each country exports goods that it owns in abundance, and imports other countries from other countries).

3.1.4 Theory with whom you trade?

Presented by Steven Lander

This theory was based on the fact that countries can trade with each other with the following criteria:

(Geographical convergence - convergence in living standards - convergence in customs, traditions and religions convergence in tastes - convergence in the levels and size of markets).

\subsection{Modern theories}

\subsection{1: External Trade Theory}

This theory was based on (Why do companies trade with abroad?):

a. Take advantage of untapped potential. It produces less than its capacity because the local market does not absorb everything that the company produces.

b. Reduce costs. This is done by expanding production, so new markets are sought.

c. Make additional profits. You can charge a high price for a commodity in countries that need those commodities a lot.

d. Diversify and reduce risks.

e. Reliance on a single market increases risks.

f. Import and supply guarantee.

g. Abundance of raw materials in other countries at lower price or high quality.

\subsubsection{Competitive Advantage Theory}

At the World Economic Forum in Davos, Switzerland, it stated that the competitiveness index is based on eight factors:

a. The degree of openness in the country.

b. The type of government.

c. Availability of financial institutions.

d. The quality of the structural structures in the country.

e. Technology and its degree of advancement.

f. The type of management.

g. National employment.

h. Civil society institutions.

3.2.3 Causes of competitive advantage between countries

Then Michael Porter, after a study he conducted, formulated four causes called (the diamond model) that lead to building and maintaining competitive advantage ( Porter, M.E.\& stern, S. 1999.p54):-

1- Resource Status

2- Volume and skill cost of labor.

3-The abundance, quality, cost and accessibility of natural resources.

4-The state's repertoire of knowledge, including technical and marketing knowledge that affects the quality of goods and services.

5-The volume and cost of capital available to the industry.

6- The type and cost of using the structures.

3.2.4 Demand Status: The competitive advantage of organizations increases if there is a strong internal demand for their goods and services:-

1- Auxiliary and related industries: For example, the existence of cooperation between shoe makers and leather producers in the same country, which gives it a competitive advantage.

2- The strategy and structure of the company and competition: The use of a successful management method, attracts the most efficient workers, which increases the competitive advantage. 
From here our mission emerged after recounting all of this, which is what necessitated the decision-makers in contemporary organizations to choose creative, pro-active strategies to face the challenges that they are likely to face with the aim of their survival and growth in the field of competition and the search for the advantage that each successful organization seeks and took upon itself to draw for itself. In order to enhance its organizational strength.

\subsection{The Concept of Creativity and Its Types}

Clayton Christensen first released the phrase disruptive technology in (1997), in his book The Innovator'sCrisis: When New Technology Causes Big Business to Fail.

It was at this time shown for the second time that all the organizations have died or departed from their industries (because of the presentation of a new model to the customer) as it may seem that the disruption is coming, and nothing can be done until it is too late.

By doing what good companies are supposed to do - in terms of going to the most acquiring customers and directing investments where there is a more attractive profit margin.

The founders of the industry get on the path of innovations left, leaving themselves vulnerable to technological disruption to bury them. This happens because resource exchanges from established firms are designed to increase profits through residual innovations, which essentially include better design and mouse-trap for existing customers or market penetration. When disruptive innovations appear (particularly cheaper, simpler to use than existing products aimed at low-end or entirely new customers), established companies cripple. They have the urge to penetrate high-end markets rather than defending the new or low-end markets, and finally, disruptive innovation improves, steals many marketing shares, and replaces the dominant product.

\subsubsection{Types of Creativity}

Businesses have two primary options when looking to build a modern business growth. They can try to take the existing markets from competitors that are protected from the remaining innovations, such as the administrative innovation, which we will mention in a later resource. (kotler:2000:p555)

Or they can try to take out competition from disruptive innovations that create new markets or take root from the worst customers.

There are two distinct types of disruptive innovations (Rossman,1931p77):-

The first type creates a new market by targeting non-customers.

The second competes at the low end of the established market.

\subsubsection{The origin of the disruptive creativity model. Date Christensen Research and Studies at Harvard.}

\subsubsection{1: Steps at the Core of Disruptive Creativity}

The model shows that, as the performance required of customers in the existing market increases over time, performance is also provided within the technology model. The performance improvement available often has a different path than the performance improvement path the customer requires (kim\&maubrogeL1997:p44)

When the path regression varies, and the available performance exceeds the required performance, modern technology that was competitive performance only in remote and high-level markets may migrate to another network for the customer. providing innovators and pushing new customers, who have previously judged their offerings as substandard; It enables them to provide key market foundations for a new set of performance value that is now more compatible than the current model.( Gareth and others,2008p76)

Ripping and commodification are actually related to hand in hand. A company that exceeds its targeting simply cannot win. A company that improves the product to a more than good degree will have enough customers to use it and pay for it. Either shredding will steal its markets, or the commodity will steal its profits. During the new waves of disruption that are taking place in the industry, money will be channeled through the value chain over time. While this is happening, companies that position themselves at the center of the value chain and where the performance is not good enough will succeed to make a profit.

\subsubsection{2: Determinants of deconstructive creativity}

3.3.2.3: Disruptive creativity requires a separate strategic process. This process should be contingency and focused on unexpected opportunities, problems and success, rather than on a developed understanding of what does and does not work.

3.3.2.4: Instead of designing products and services that address the current behavior of existing customers, people-oriented goals must align with design innovations. Understanding what people really need is generally far from 
available.

Disruptive businesses cannot achieve very high profits quickly, due to their nature in terms of addressing the new market, or addressing the low end of the existing markets, as the venture depends increasingly on a little patience in the business to receive profits

\subsection{Conditions for reliance on disruptive creativity}

Companies risk to death with decisions that ignore technology and do not address the needs of customers, and become deadly when there are two exemplary paths of inter-action of progress.

Here we can recall the Ansoff model of product / market strategies. To proceed from his own disruptive creativity matrix, which consists of focusing on the following things:-

1-Market penetration strategy:

2-Pushing existing products to existing markets

3 Market development strategy:

4-Pushing existing products to new markets

5-Product development strategy:

6-Promoting new products for existing markets.

7-Diversification strategy: It includes diversification in:

a-Horizontal diversification: controlling new businesses that complement the company's current activity

b-Mixed diversification: entering into new activities different from the company's current activity

c-Vertical integration: controlling the activities of suppliers (inputs), i.e. backward integration, and controlling the activities of distributors (outputs), i.e. forward integration

\subsection{Interpreting Disruptive Innovation}

The concept was first introduced by Clayton Christensen of Harvard Business School in 1997.

In his famous book (The Innovator'sCrisis) (Al-Mousawi 2009: 67)

The concept that is, the use of modern technology to tear up or penetrate the market of the strongest competitor, which leads to its bankruptcy and failure, and then its withdrawal to other markets, which makes it withdraw or give up its product for those companies that invented technology in a period of weakness and penetrated the market for their products. Then the defeated company resorted to other new innovations. (Evans 1997:p88)

\section{The Third Topic: Strategic neglect or the problem of strategic management}

\subsection{The Problem of Strategic Management}

It can be described as an ordinary management problem and an extraordinary problem

(Rowe \& Ventas: 2008p62) The strategic problem may be closed truth or open truth, the ordinary problem has definite limits and adheres to acceptable limits, and the manager sees ordinary problems with acceptable probabilities about what that problem is and works under an acceptable and known model that has become or appears typical.

The solutions to the problem may be known, understandable and acceptable to managers and consider them simple through procedures or make acceptable options among known latent solutions based on known management criteria such as (profit, growth, market share).

Ordinary problems may look like puzzles or rules of play.

As for the exceptional management or the exceptional problem, it is more problematic or difficult than the problem with the apparent truth, as it is not very well known and is not accepted. acceptable performance, while the ordinary problem requires moderate things to maintain order, the exceptional problem requires breaking the routine or the paradigm by inventing a new and unfamiliar paradigm. (Vermeulen, \&others.: 2014p76)

Some researchers suggest a new role for the researcher to assume in discovering a hidden and wide range of expectations. Usually this range is very exceptional. It pushes the expectations of the normal administration forward by means of high throws not agreed upon by the administration, and that is through the continuous pursuit of several experiments to solve the contradictions through a combination of strategies or organizational contexts that mediate those multi-volatile environments. (fitzgerald L AND Enjnatten ,2002p412)

We all know that the mentioned strategies are matched by appropriate systems or environments for their implementation 
(Rowe \& Ventas: 2008p17))

(Sameer Vaidya:2009:p14) believes that many things are involved in the issue of partnership, which is the key to success. Venturing in investments through choosing the allied partner depends on several things related to the negotiating ability of the organization and related to the motives from which the formation of alliances emerges. Negotiation includes trust, conflict and control. Commitment, learning, experience, and consistency. The motives have been divided into three parts: internal advantages, competitive advantages, and strategic benefits.

(1) Internal benefits. Alliances are often formed to generate internal power and internal benefits include sharing costs and risks, obtaining scarce resources, obtaining financing, obtaining information, obtaining management expertise, and retaining creative employees.

(2) Competitive advantage. Alliances are a powerful tool for creating competitive strengths through vertical integration or standardization of values. Competitive benefits include industry structure, anticipating competitors, responding to globalization, and creating more effective competitors. (Katerina Kareska1 , Ljupco 2009p5)

(3) Strategic benefits. Joint stock companies help companies implement change in their strategic position. Strategic advantages include creating and exploiting synergies, technology transfer, and diversification.

And some of them explain or link what leads to the success of alliances with three reasons(Mashic, B.,2001p45)

Namely: (A) Transaction cost approach. Alliances are formed to reduce production cost for companies. When production costs from internalization exceed the cost of external sources then alliance formation is a viable option.

(B) Strategic behavior approach. This approach assumes that alliances were formed in response to external environmental pressures.

(C) Organizational Learning Approach. It allows the alliance to experience knowledge or know-how from another company.

Organizations that intend to engage in joint investment adventures usually do a comprehensive and complex analysis of strengths, weaknesses, opportunities and threats before deciding on forming an alliance. The researcher believes that one or more of the above-mentioned motives may be a convincing and sufficient reason to enter into alliances in most commercial organizations.

according to see(Vaidya:2009PP8)

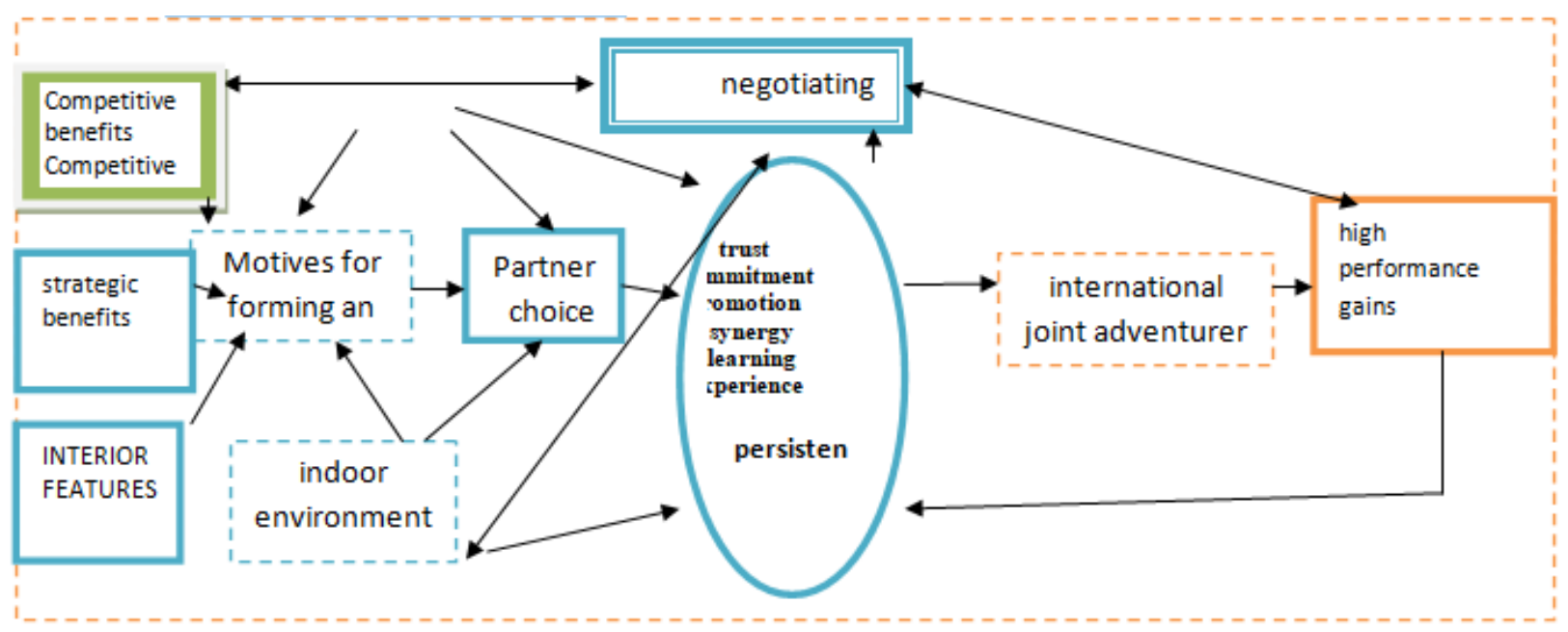

Figure 2. Matters related to alliances and related motives

Source: Sameer Vaidya (2009) International joint ventures: an integrated framework Wesleyan University, Fort Worth, Texas, USA Competitiveness Review: An International Business Journal Vol. 19 No. 1, 2009 pp. 8-16 q Emerald Group Publishing Limited 1059-5422 DOI 10.1108.p14.

According to (Qalash: 2009, p. 5), strategic alliances: occur as a result of the increasing competition between business organizations in order to control markets and resources, and as a result of the parties' conviction of the futility of competition that may cause great economic loss. Alliances began to appear as an alternative and as a strategic option between Business organizations in order to either share markets or resources or take advantage of the capabilities and expertise of others, strategic alliances have appeared in several forms, including: joint venture, subcontracting, financial alliance, marketing alliance, technology alliance, and lending. 


\section{The Forth Topic: the field aspect and the research scale test}

Below is the scale adopted in this research, which was designed by the researcher in the light of the sources from which the researcher quoted his ideas (Sameer Vaidya: 2009: p14) and was applied to commercial organizations (trade range and spectrum)

5.1 Table (1) shows the independent variable and its sub-dimensions (requirements for the initiative in strategic alliances (code K1 )).

\begin{tabular}{|c|c|c|c|c|c|c|c|}
\hline \multirow[t]{2}{*}{ sub dimension } & \multirow[t]{2}{*}{ code } & \multirow[t]{2}{*}{ expressive paragraph } & \multicolumn{5}{|c|}{ measuring scale } \\
\hline & & & $\begin{array}{l}\text { Totally } \\
\text { agree }\end{array}$ & $\begin{array}{l}\text { I } \\
\text { agree }\end{array}$ & Neutral & $\begin{array}{l}\text { I don't } \\
\text { agree }\end{array}$ & $\begin{array}{l}\text { don't } \\
\text { totally } \\
\text { agree }\end{array}$ \\
\hline \multirow{2}{*}{$\begin{array}{l}\text { trust } \\
\text { The power of } \\
\text { negotiation }\end{array}$} & $\mathrm{A} 1$ & $\begin{array}{l}\text { Our organization focuses on trust in the } \\
\text { differentiation of investors }\end{array}$ & & & & & \\
\hline & A2 & $\begin{array}{l}\text { Our organization has powerful negotiating } \\
\text { energies that win deals }\end{array}$ & & & & & \\
\hline \multirow[t]{2}{*}{ Commitment } & A3 & $\begin{array}{l}\text { It is important for our organization that the partner } \\
\text { is abiding by all the standards of the agreements. }\end{array}$ & & & & & \\
\hline & A4 & $\begin{array}{l}\text { Commitment is a commodity to leaders and an } \\
\text { important tool for engagement and efficiency }\end{array}$ & & & & & \\
\hline \multirow[t]{2}{*}{ censorship } & A5 & $\begin{array}{l}\text { One of the topics in which Hassan's organization } \\
\text { stands out is the way it monitors the internal and } \\
\text { external environments }\end{array}$ & & & & & \\
\hline & A6 & $\begin{array}{l}\text { Oversight is one of the most important pillars of } \\
\text { the success of our organization because it is very } \\
\text { proficient and always follows up on its results }\end{array}$ & & & & & \\
\hline \multirow[t]{2}{*}{ synergy } & A7 & $\begin{array}{l}\text { Our organization believes that disagreements and } \\
\text { disputes must find a path for negotiation }\end{array}$ & & & & & \\
\hline & A8 & $\begin{array}{l}\text { Conflict occurs when employees vote on financial } \\
\text { actions No. }\end{array}$ & & & & & \\
\hline \multirow[t]{2}{*}{ learning } & A9 & $\begin{array}{l}\text { As workers and leaders, we benefit from what is } \\
\text { happening around us in our field of specialization } \\
\text { and our markets }\end{array}$ & & & & & \\
\hline & A10 & $\begin{array}{l}\text { Lessons and lessons that we draw from our } \\
\text { experiences to learn from to improve our } \\
\text { performance }\end{array}$ & & & & & \\
\hline \multirow[t]{2}{*}{ Experience } & A11 & $\begin{array}{l}\text { Our experience accumulates whenever we deal } \\
\text { with competing products and organizations }\end{array}$ & & & & & \\
\hline & A12 & $\begin{array}{l}\text { We, as individuals, employees and leaders, care } \\
\text { about knowledge and information acquisition in } \\
\text { business }\end{array}$ & & & & & \\
\hline \multirow[t]{2}{*}{ stability } & A13 & $\begin{array}{l}\text { Staying in our jobs makes us more stable for } \\
\text { performance and efficiency }\end{array}$ & & & & & \\
\hline & A14 & $\begin{array}{l}\text { Training, perseverance and ambition make us } \\
\text { perform stable and for the better. }\end{array}$ & & & & & \\
\hline
\end{tabular}




\subsection{The Intermediate Variable and Its Symbol Requirements Creativity Shredder (code K2)}

Table (2) shows the dimensions of the moderating variable and the requirements of disruptive creativity

\begin{tabular}{|c|c|c|c|c|c|c|c|}
\hline \multirow[t]{2}{*}{ sub dimension } & \multirow[t]{2}{*}{ code } & \multirow[t]{2}{*}{ expressive paragraph } & \multicolumn{5}{|c|}{ measuring scale } \\
\hline & & & $\begin{array}{l}\text { Totally } \\
\text { agree }\end{array}$ & $\begin{array}{c}\mathrm{I} \\
\text { agree }\end{array}$ & Neutral & $\begin{array}{l}\text { I don't } \\
\text { agree }\end{array}$ & $\begin{array}{l}\text { don't } \\
\text { totally } \\
\text { agree }\end{array}$ \\
\hline \multirow[t]{2}{*}{$\begin{array}{c}\text { remove } \\
\text { obstacles }\end{array}$} & A15 & $\begin{array}{l}\text { Is the organization interested in checking all } \\
\text { performance obstacles and trying to solve } \\
\text { them? }\end{array}$ & & & & & \\
\hline & A16 & $\begin{array}{l}\text { Is the organization doing some strategic } \\
\text { maneuvers to get rid of the obstacles of new } \\
\text { entrants and competitors in its markets? }\end{array}$ & & & & & \\
\hline \multirow[t]{2}{*}{ ditching } & A17 & $\begin{array}{l}\text { Does your organization master the } \\
\text { competitiveness and use methods of } \\
\text { competition and master the challenges faced? }\end{array}$ & & & & & \\
\hline & A18 & $\begin{array}{l}\text { Does the organization counter competitive } \\
\text { attacks through a set of motivation strategies? }\end{array}$ & & & & & \\
\hline \multirow[t]{2}{*}{$\begin{array}{l}\text { competitor } \\
\text { penetration }\end{array}$} & A19 & $\begin{array}{c}\text { Our organization follows creative methods to } \\
\text { tear the ranks of competitors? }\end{array}$ & & & & & \\
\hline & $\mathrm{A} 20$ & $\begin{array}{l}\text { Through communications and informational } \\
\text { methods, our organization penetrates the details } \\
\text { and plans of competitors? }\end{array}$ & & & & & \\
\hline \multirow{2}{*}{$\begin{array}{c}\text { seize } \\
\text { opportunities }\end{array}$} & A21 & $\begin{array}{l}\text { My organization is keen to early in the } \\
\text { introduction of the new product? }\end{array}$ & & & & & \\
\hline & A22 & $\begin{array}{l}\text { My organization is interested in following up the } \\
\text { information, tastes and trends of customers in } \\
\text { order to get the winning orders? }\end{array}$ & & & & & \\
\hline \multirow[t]{2}{*}{$\begin{array}{l}\text { Structure } \\
\text { flexibility }\end{array}$} & A23 & $\begin{array}{c}\text { My organization always tries to rotate with } \\
\text { efficient jobs and leaders? }\end{array}$ & & & & & \\
\hline & $\mathrm{A} 24$ & $\begin{array}{l}\text { My organization is keen to allow technology to } \\
\text { eliminate red tape and nepotism? }\end{array}$ & & & & & \\
\hline
\end{tabular}




\subsection{The Intermediate Variable and Its Symbol: Performance Gain Higher-(code K3)}

Table (3) Dimensions of the dependent variable: high performance gains

\begin{tabular}{|c|c|c|c|c|c|c|c|}
\hline \multirow[t]{2}{*}{ sub dimension } & \multirow[t]{2}{*}{ code } & \multirow[t]{2}{*}{ expressive paragraph } & \multicolumn{5}{|c|}{ measuring scale } \\
\hline & & & $\begin{array}{l}\text { Totally } \\
\text { agree }\end{array}$ & I agree & Neutral & $\begin{array}{l}\text { I don't } \\
\text { agree }\end{array}$ & $\begin{array}{l}\text { don't } \\
\text { totally } \\
\text { agree }\end{array}$ \\
\hline \multirow[t]{2}{*}{$\begin{array}{l}\text { Successful } \\
\text { competitive } \\
\text { advantages }\end{array}$} & A 25 & $\begin{array}{l}\text { Does management understand that } \\
\text { some partial performance measures } \\
\text { can reduce overall performance? }\end{array}$ & & & & & \\
\hline & A26 & $\begin{array}{l}\text { Does the organization extend its } \\
\text { competitive activities to the extent and } \\
\text { oceans of expansion in various } \\
\text { markets? }\end{array}$ & & & & & \\
\hline \multirow[t]{2}{*}{ product leadership } & A 27 & $\begin{array}{l}\text { Do performance measures put pressure } \\
\text { in the right directions for } \\
\text { improvement? }\end{array}$ & & & & & \\
\hline & A28 & $\begin{array}{l}\text { Does the organization take advantage } \\
\text { of the growth times in the product life } \\
\text { cycle in order to diversify its } \\
\text { leadership styles? }\end{array}$ & & & & & \\
\hline \multirow[t]{2}{*}{$\begin{array}{l}\text { Operational } \\
\text { superiority }\end{array}$} & A29 & $\begin{array}{l}\text { Has management determined success } \\
\text { by identifying biometrics by function, } \\
\text { process, and activity? }\end{array}$ & & & & & \\
\hline & A 30 & $\begin{array}{l}\text { Does the organization maintain its } \\
\text { structural capabilities in terms of } \\
\text { production and operation? }\end{array}$ & & & & & \\
\hline \multirow[t]{2}{*}{ earnings reports } & A 31 & $\begin{array}{l}\text { Does the performance measurement } \\
\text { system improve by providing early } \\
\text { warning signals that support a } \\
\text { proactive management approach? }\end{array}$ & & & & & \\
\hline & A 32 & $\begin{array}{l}\text { Does the organization rely on modern } \\
\text { accounting methods in order to } \\
\text { improve its profit statements? }\end{array}$ & & & & & \\
\hline \multirow[t]{2}{*}{$\begin{array}{l}\text { Long-term } \\
\text { stakeholder value }\end{array}$} & A33 & $\begin{array}{l}\text { Does your existing performance } \\
\text { measurement system help integrate } \\
\text { your company's people, processes, and } \\
\text { activities for better overall } \\
\text { performance }\end{array}$ & & & & & \\
\hline & A34 & $\begin{array}{l}\text { Does the organization make } \\
\text { exceptional considerations for } \\
\text { stakeholder value to maintain them? }\end{array}$ & & & & & \\
\hline
\end{tabular}

And based on what he sees (Christopher \& others: 2003p721) and to obtain the stability and accuracy of the scale designed by the researcher for this purpose, the quality of acceptance of the measurement indicators was adopted through the response rates of the (10) respondents (arbitrators) in the field of business administration on the importance of the two variables, the interpreter and the respondent. 
Table 4 . The quality of the measuring instrument

\begin{tabular}{|c|c|c|c|c|c|c|c|c|}
\hline \multirow{2}{*}{$\begin{array}{l}\text { independent } \\
\text { variable } \\
\text { Initiating } \\
\text { strategic } \\
\text { alliances } \\
\end{array}$} & \multicolumn{8}{|c|}{ The adopted variable is achieving long-term success or achieving gains in investment performance } \\
\hline & $\begin{array}{l}\text { successful } \\
\text { competitive } \\
\text { advantage }\end{array}$ & $\begin{array}{l}\text { product } \\
\text { leadership }\end{array}$ & $\begin{array}{l}\text { customer } \\
\text { interaction }\end{array}$ & $\begin{array}{l}\text { Operational } \\
\text { Excellence }\end{array}$ & $\begin{array}{l}\text { Operational } \\
\text { Excellence }\end{array}$ & $\begin{array}{l}\text { Improving } \\
\text { earnings } \\
\text { reports }\end{array}$ & $\begin{array}{l}\text { Long-term } \\
\text { stakeholder } \\
\text { value }\end{array}$ & $\begin{array}{l}\text { Scale quality = sum of } \\
\text { averages divided by } \\
\text { their number }\end{array}$ \\
\hline $\begin{array}{l}\text { trust } \\
\text { The power of } \\
\text { negotiation }\end{array}$ & 4.897 & 5.424 & 3.761 & 2.998 & 2.889 & 3.444 & 4.762 & $\begin{array}{l}\text { 3.875Acceptable } \\
\text { Quality }\end{array}$ \\
\hline Commitment & 5.236 & 5.865 & 2.876 & 4.212 & 4.332 & 2.945 & 3.781 & $\begin{array}{l}\text { 3.796Acceptable } \\
\text { Quality }\end{array}$ \\
\hline censorship & 4.878 & 4.982 & 4.123 & 3.878 & 4.091 & 2.871 & 3.900 & $\begin{array}{l}\text { 3.924Acceptable } \\
\text { Quality } \\
\end{array}$ \\
\hline synergy & 3.894 & 3.861 & 3.912 & 4.887 & 3.990 & 3.767 & 4.541 & $\begin{array}{l}3.771 \\
\text { Acceptable Quality }\end{array}$ \\
\hline learning & 2.987 & 3.994 & 5.341 & 4.989 & 2.871 & 4.878 & 3.955 & $\begin{array}{l}3.7564 \\
\text { Acceptable Quality }\end{array}$ \\
\hline Experience & 1.893 & 5.876 & 2.876 & 5.003 & 1.989 & 2.444 & 3.860 & $\begin{array}{l}3.453 \\
\text { Acceptable Quality }\end{array}$ \\
\hline stability & 3.999 & 4.876 & 3.112 & 4.767 & 5.888 & 2.911 & 4.561 & 4.134good quality \\
\hline The overall aver & or the qua & ndicat & neral & & & & & 3.512 \\
\hline
\end{tabular}

pheasant: (1) the lowest importance of the variable, corresponding to (6) the highest importance of the variable from the arbitrators' point of view

Hypothetical mean of quality ( 3 or more positive) (and less than 3 negative)

So the scale is acceptable with this formula according to the above modern method, as it obtained a stability ratio and from the point of view of the arbitrators $(3,512)$

As in the last field of Table (4) above.

Table 5. Below shows a summary of the statistical analysis of all three dimensions

\begin{tabular}{|c|c|c|c|c|c|c|c|c|c|c|}
\hline \multicolumn{11}{|c|}{ Summary of the results of the statistical analysis in the SPSS.VERTION $19 \mathrm{n}=25$} \\
\hline \multicolumn{6}{|c|}{ Indicators of the dampening variable, disruptive creativity } & \multicolumn{5}{|c|}{$\begin{array}{l}\text { Indicators of the independent variable, requirements for } \\
\text { leadership initiative }\end{array}$} \\
\hline $\max$ & Min & $\begin{array}{c}\text { Standar } \\
\text { d .deviat } \\
\text { ion }\end{array}$ & Mean & Compo & & $\max$ & Min & $\begin{array}{l}\text { Standard } . d \\
\text { eviation }\end{array}$ & Mean & Composition \\
\hline 5 & 2 & 0,45 & 3,42 & remove o & & 5 & 3 & 0.38 & 2.85 & trust \\
\hline 5 & 1 & 0,48 & 2,92 & ditching & & 5 & 2 & 0.48 & 2,55 & Commitment \\
\hline 5 & 3 & 0,56 & 3,52 & hack & & 5 & 1 & 0,54 & 2,47 & censorship \\
\hline 5 & 2 & 0,56 & 2.56 & $\begin{array}{l}\text { seize } \\
\text { opportuni }\end{array}$ & & 5 & 2 & 0,36 & 2,33 & conflict \\
\hline \multirow[t]{3}{*}{5} & \multirow[t]{3}{*}{1} & \multirow[t]{3}{*}{0.62} & \multirow[t]{3}{*}{2,37} & \multirow{3}{*}{\multicolumn{2}{|c|}{$\begin{array}{l}\text { Flexible } \\
\text { Structure }\end{array}$}} & 5 & 1 & 0.48 & 2,21 & Experience \\
\hline & & & & & & 5 & 1 & 0,56 & 2,17 & learning \\
\hline & & & & & & 5 & 2 & 0,61 & 2,56 & $\begin{array}{l}\text { stability or } \\
\text { stability }\end{array}$ \\
\hline \multicolumn{11}{|c|}{ Dependent variable: high performance gains } \\
\hline \multicolumn{2}{|c|}{ composition } & earnings report & \multicolumn{2}{|r|}{$\begin{array}{l}\text { Operational } \\
\text { superiority }\end{array}$} & & $\begin{array}{l}\text { product } \\
\text { eadership }\end{array}$ & & $\begin{array}{l}\text { Successful } \\
\text { competitive } \\
\text { advantages }\end{array}$ & \multicolumn{2}{|c|}{ Stakeholder value } \\
\hline \multicolumn{2}{|c|}{ mean } & \multicolumn{2}{|l|}{3.21} & 2.95 & & 4,25 & & 3,31 & \multicolumn{2}{|r|}{3.05} \\
\hline \multicolumn{2}{|c|}{ St.d } & \multicolumn{2}{|l|}{0.35} & 0.65 & & 0.43 & & 0.62 & \multicolumn{2}{|r|}{0.61} \\
\hline \multicolumn{2}{|c|}{$\max$} & \multicolumn{2}{|l|}{5} & 5 & & 5 & & 5 & \multicolumn{2}{|r|}{5} \\
\hline \multicolumn{2}{|c|}{$\min$} & 1 & \multicolumn{2}{|r|}{2} & & 1 & & 2 & \multicolumn{2}{|r|}{3} \\
\hline
\end{tabular}


Source: - computer outputs using the statistical program Spss

From the above table, it is clear that the investment organizations investigated in Basra did not achieve high performance, but rather moderate performance, respectively, with the variable of product leadership, successful competitive advantages, the variable of earnings reports, and the value of long-term stakeholders, and they failed in the variable of operational and operational excellence.

Its arithmetic means and standard deviations were, respectively, as follows:-

The first: the product's driving variable as it reaches its arithmetic mean

$(4,25)$, which is in the first order among all the sub-dependent dimensions, and the deviation of the answers of the sample members from its arithmetic mean is

(0.43) Referring to their agreement on the mentioned dimension and the lack of dispersal of their answers. In an indication of the interest of these organizations to lead the product in the markets and in various possible ways, which indicates something, it indicates their keenness to seize the life cycle of the product at the stage of financial generation.

The second: a variable of successful competitive advantages, as it reached its arithmetic mean

$(3,31)$, which is in the first order among all the sub-dependent dimensions, and the deviation of the answers of the sample members from its arithmetic mean is

(0.63) Referring to their agreement on the mentioned dimension and the lack of dispersal of their answers. It is an indication of the interest of those organizations in competitive advantage, customer satisfaction and achieving the market share.

Celebrate the occasion and get a good position in its markets and in the minds of its customers and stakeholders.

And so on for the rest of the details, one by one.

Table (6) Correlation between the independent variable (x) and the dependent variable (y)

\begin{tabular}{lllllll}
\hline $\mathrm{n}$ & $\mathrm{x}$ & $\mathrm{y}$ & $\mathrm{x}$ sort & $\mathrm{y}$ sort & $\mathrm{d}$ & $\mathrm{d}^{2}$ \\
\hline 1 & 2.85 & 3,31 & 1 & 2 & 1 & 1 \\
2 & 2,55 & 3.05 & 3 & 5 & 2 & 4 \\
3 & 2,47 & 3.21 & 4 & 4 & 0 & 0 \\
4 & 2,33 & 2.95 & 5 & 7 & 2 & 4 \\
5 & 2,21 & 4,25 & 6 & 1 & $5-$ & 25 \\
6 & 2,17 & 3,31 & 7 & 3 & $4-$ & 16 \\
7 & 2,56 & 3.05 & 2 & 6 & 4 & 16 \\
\end{tabular}

$\mathrm{R}=1-(6 * 66) / 7 * 48$

$=1-(396 / 336)$

$=1-1.178$

$\mathrm{R}=-0.178$ weak negative correlation

It is very weak, but positive $r^{2}=0.031$ Either $t$ computed

$\mathrm{T}=\mathrm{r} \sqrt{\mathrm{n}}-2 / 1-\mathrm{r}^{2}$

$0.178 \sqrt{ } 1 / 1-0.031-$

$=-0.178 \sqrt{ } 1 / 0.996$

$=-0.178 \sqrt{ } 1.0040$

$=-0.178 * 1.001999=-1.18035$ 
So the calculated $t$ and the negative sign is not taken into account $=1.180$ which is higher than the tabular amount of (0.329) (Mohsen and Al-Najjar 2009:79)

Table 7. Shows the coefficient of influence and correlation between the variables of initiative and disruptive creativity, $n$ $=25$

\begin{tabular}{|c|c|c|c|c|c|c|c|}
\hline \multirow[b]{2}{*}{ Variables } & \multicolumn{6}{|c|}{ The dimensions of the adopted variable combined (success or high performance gains) } & \multirow[b]{2}{*}{ Interpretation } \\
\hline & Code & $\begin{array}{c}\text { A8 Remove } \\
\text { Obstacles }\end{array}$ & ditching A9 & A10 hack & $\begin{array}{c}\text { A11 seize } \\
\text { opportunities }\end{array}$ & $\begin{array}{c}\text { A12 Flexible } \\
\text { Structure }\end{array}$ & \\
\hline trust & A1 & 0.34 & 0.76 & 0.56 & 0.45 & 0.65 & \multirow{7}{*}{$\begin{array}{l}\text { Most of the values } \\
\text { are significant } \\
\text { in sign of } \\
\text { The answers of the } \\
\text { sample members } \\
\text { agree with the } \\
\text { researcher's point of } \\
\text { view }\end{array}$} \\
\hline Commitment & A2 & 0.45 & 0.54 & 0.89 & 0.78 & 0.77 & \\
\hline censorship & A3 & 0.46 & 0.77 & 0.88 & 0.56 & 0.79 & \\
\hline synergy & A4 & 0.89 & 0.46 & 0.68 & 0.85 & 0.91 & \\
\hline Experience & A5 & 0.73 & 0.44 & 0.76 & 0.63 & 0.82 & \\
\hline learning & A6 & 0.43 & 0.76 & 0.85 & 0.89 & 0.81 & \\
\hline stability & A7 & 0.88 & 0.73 & 0.37 & 0.76 & 0.88 & \\
\hline
\end{tabular}

Source: - Computer outputs using the statistical program, the Social Sciences package spss.v19

Table 8 . Testing the validity of hypotheses $n=25$

\begin{tabular}{|c|c|c|c|c|c|c|c|}
\hline \multirow[b]{2}{*}{ Variables } & \multicolumn{7}{|c|}{ The dimensions of the adopted variable combined (success or high performance gains) } \\
\hline & CODE & $\mathrm{R}$ & $\mathrm{R} 2$ & $\begin{array}{c}\text { T- } \\
\text { calculated }\end{array}$ & T-tabular & $\begin{array}{c}\text { Level of } \\
\text {.significance }\end{array}$ & Interpretation \\
\hline trust & A1 & \multirow{7}{*}{-0.178} & \multirow{7}{*}{$\mathrm{r}^{2}=0.031$} & \multirow{7}{*}{1.18035} & \multirow{7}{*}{0.329} & \multirow{7}{*}{0.000} & \multirow{7}{*}{$\begin{array}{c}\text { Since t } \\
\text { The calculated is } \\
\text { higher than the } \\
\text { tabular, so the } \\
\text { hypotheses are } \\
\text { accepted }\end{array}$} \\
\hline Commitment & $\mathrm{A} 2$ & & & & & & \\
\hline censorship & A3 & & & & & & \\
\hline synergy & A4 & & & & & & \\
\hline Experience & A5 & & & & & & \\
\hline learning & A6 & & & & & & \\
\hline stability & A7 & & & & & & \\
\hline
\end{tabular}

Source: - Computer outputs using the statistical program, Spss.v19

So There is a relationship of influence and a statistically significant correlation between the two independent variables (the interpreter), which is the variable of the strategic initiative of the alliance in terms of disruptive creativity and the approved responsive achieve success in the high performance of the surveyed companies (range and spectrum)

\section{The Fifth Topic: conclusions and recommendations}

\subsection{The Conclusions}

1. It turned out that the variables of trust, negotiating energies, commitment, control, conflict, experience, learning, flexibility, and stability were at a moderate level in the surveyed organizations, which is evidence of poor awareness of them by the leaders of those organizations. As alliances need the availability of these indicators to enjoy the attributes of an enterprising leader, which is what their leaders lack at the moment.

2. The disruptive creativity variable supports and enhances the state of control and follow-up of the market and competitors in particular, which calls for its adoption in future studies and applications to achieve the required retrenchment in the direction of competitive weapons for competitors in the field of investment practiced by the two researched companies

3. The results of the analysis showed a weak but positive correlation and effect regarding the contribution to achieving long-term success from performance gains and tested strategic alliances. This is reinforced by the t-test that showed the superiority of the calculated t-value over the tabular t-value, which reinforces and proves the two initial hypotheses in the current research . 
4. It became clear from the results of the statistical analysis that there is a weakness in the two companies surveyed in the operational superiority compared to the level of competitive performance required. Through the analysis, this became clear, and if it indicates something, it indicates an intellectual and cultural deficiency in the field of capital and investment operation in them.

5. It turns out that there is a weakness in the investment competitive advantages of the two companies surveyed, which is one of the most important pillars of long-term success due to the lack of competitive talents among their leaders at the present time.

\subsection{The Recommendations}

1. The need to raise concepts and indicators (confidence, negotiating ability, commitment, control, conflict, experience, learning, flexibility and stability) and to raise awareness of them in the two organizations surveyed, through increasing the administrative development activities of leaders and improving the level of awareness of them.

2. It is important to adopt disruptive creativity and its mechanisms discussed in the two companies to continue to withstand the annoying moves of competitors, by integrating advanced intellectual energies from leaders and administrative positions with conferences and development programs in the field of leadership and creativity.

3. Enhancing the operational capacity and financial leverage of the financial center and trying to improve profit reports in a way that ensures survival in the investment market.

4. It is beneficial for the two companies to improve their competitive advantages in order to maintain their market share and to remain as much as possible in a balanced level in the financial and investment field.

\section{References}

\section{First:- Arabic references}

\section{A:books}

Abdullah Qalash. (2009). Modern Trends in Administrative Thought, Washington Center for Strategic Studies. Imam Shirazi International Institute for Studies www.siironline.org.

Abdul Karim Mohsen and Sabah Abdul Majeed Al Najjar. (2009). Production and Operations Management, first edition, Amman, Jordan.

\section{B:journals:}

Al-Mousawi, Batoul Attia Khalaf. (2009). The Impact of Technological Creativity on the Development of the Company's Products. Journal of Administration and Economics, a case study in the General Company for Electrical Industries, University of Baghdad, Issue Seventy-eighth. From p. 53 - p. 83)

\section{Secondly, foreign references}

\section{A: Books}

Christopher \&Lttner \&David and Taylor. (2003). (performance implications of strategic performance measurement in financial services firms) accounting ,organizations and society, 28.2003,715-741.

Rossman. (1931). httpll working papcrs: Innoratconmodols.com.(1931 ) http//working papcts.Innoratconmodols.com. Jim Rowe \&Ventas. (2008). studying strategy" publishing Aps.ISBN978-87-7687-420-5

Jarzabkowski, P., Smets, M., Bednarek, R., Burke, G., \& Spee, P. (2013). Institutional Ambidexterity: Leveraging Institutional Complexity in Practice. Research in the Sociology of Organizations, 39, 37-61.

Kotler, Philip. (2000). Marketing Management. the millenniumed, prentice- Hall Inc. New Jersey.

Katerina Kareska1, Ljupco Davcev. (2019). Challenges in modern management and modern business that Macedonian organizations face in gaining competitive advantage.

Mashic, B. (2001). "Strategic management","Braca Karic" University, Belgrade.

Porter, M. E. \& Stern, S. (1999). The New Challenge to America's prosperity: Findings from the innovation index, Council on competitiveness", Washington.

\section{B: Journals:-}

Evans James R. (1997). Production Operations Management Quality Performance \& Value “ 5th edition West Pub Co. New York . 
Fitzgerald L and Enjnatten. (2002). Refection chaos in organization change. journal of organization change management, 15, 402-411.

Kim, \& Maubroge, "Value Innovation: (1997). The strategicLongic of High Growth", Harvard Business Review, Jan, 1997).

Sameer Vaidya. (2009). International joint ventures: an integrated framework Wesleyan University, Fort Worth, Texas, USA Competitiveness Review: An International Business Journal Vol. 19 No. 1, 2009 pp. 8-16 q Emerald Group Publishing Limited 1059-5422. https://doi.org/10.1108/10595420910929022.

Vermeulen, P., Zietsma,C., Greenwood, R., Langley, A. (2014). Special issue of Strategic Organization: Strategic Responses to Institutional Complexity. Journal of Strategic Organization, 12(1), 79-82.

\section{Copyrights}

Copyright for this article is retained by the author(s), with first publication rights granted to the journal.

This is an open-access article distributed under the terms and conditions of the Creative Commons Attribution license which permits unrestricted use, distribution, and reproduction in any medium, provided the original work is properly cited. 